\title{
Empirical Analysis on the Current Status and the Development of Bilateral Trade according to the Promotion of Korea-Japan FTA
}

\author{
Jin-Gu Kang1), Jon-Mo Yoon²)
}

\begin{abstract}
The purpose of this paper was to explore the direction of development of trade between South Korea and Japan prior to the conclusion of the South Korea-Japan Free Trade Agreement ("FTA"). This study examined the volume of trade between South Korea and Japan and related characteristics, and derived empirical results using yearly data for 27 years from 1991 to 2017. According to the results of the analysis, the higher GDPs of South Korea and Japan as well as South Korean direct investments in Japan had positive $(+)$ effects on the volumes of trade between South Korea and Japan. On the other hand, it was identified that Japanese direct investments in South Korea had negative (-) effects on the volumes of trade between South Korea and Japan. Furthermore, it could be seen that among the fields where Japanese invested in South Korea, the manufacturing and service industries have been on the rise in recent years, and the robust economic growth rates and the trend of expansion of mergers[1] and acquisitions of Japan led to increases in Japanese foreign direct investments, thereby affecting increases in investments in South Korea. Accordingly, it is expected that investments in various economic fields including gaming contents and information technology will become full-fledged hereafter. Therefore, in the case of the conclusion of the Korea-Japan FTA, it can be said that rather than focusing on speed, more rigorous verification is necessary for the provisions that may be concluded.
\end{abstract}

Keywords: Japan, Trade, FTA, GDP, Direct Investment

\section{Introduction}

This study is distinguished from prior studies in that it examined and analyzed the volume and trends of trade between South Korea and Japan in the advent of the Korea-Japan FTA. South Korea and Japan have prepared the foundation for the development of Northeast Asia and are developing while taking charge of a large axis of world trade. As a result, the volume of trade between the two countries exceeded U\$100 billion in 2011 and 2012, but has been

Received(April 18, 2020), Review Result(1st: June 2, 2020, 2nd: July 23, 2020), Accepted(August 28, 2020)

1) (Student) 16890 College of Business and Economics, DanKook Univ., Jukjeon-ro, Suji-gu, Yongin-si, Gyeonggi-do, Korea email: ullashon@naver.com

2) (Professor, Corresponding Author) 16890 College of Liberal Arts, DanKook Univ., Jukjeon-ro, Suji-gu, Yongin-si, Gyeonggi-do, Korea

email: jyoon2010@naver.com 
Empirical Analysis on the Current Status and the Development of Bilateral Trade according to the Promotion of Korea-Japan FTA

showing a decreasing trend, leading to a decrease below U\$100 billion in 2013 due to the low exchange rates of the yen and the negative relationship between South Korea and Japan[2]. Therefore, to review recent trends, the volumes of trade between South Korea and Japan were U\$71.8 billion in 2016 and U\$8.2 billion in 2017 and in particular, South Korea's trade deficit with Japan in 2017 was U\$28.3 billion, an increase of U\$5.2 billion compared to the same period in 2016. This figure can be attributed to the fact that Japan's world trade balance in 2017 recorded a surplus of 2,632.1 billion yen (January to November). However, special attention should be paid because the Japanese world trade balance fluctuated dramatically from $\triangle 12,787.4$ billion yen in 2014 to 2,835.3 billion yen in 2015 and to $4,070.2$ billion yen in 2016 .

[Table 1] Trends of trade of South Korea with Japan

\begin{tabular}{|c|c|c|c|c|c|c|c|c|}
\hline \multirow{2}{*}{ Year } & \multicolumn{3}{|c|}{ Export } & \multicolumn{3}{c|}{ Import } & \multicolumn{3}{c|}{ Trade balance } \\
\cline { 2 - 9 } & Total & With Japan & Ratio & Total & With Japan & Ratio & Total & With Japan \\
\hline 2015 & $526,757(-8.0)$ & $25,577(-20.5)$ & 4.9 & $436,499(-16.9)$ & $45,854(-14.7)$ & 10.5 & 90,258 & $\triangle 20,277$ \\
\hline 2016 & $495,426(-5.9)$ & $24,355(-4.8)$ & 4.9 & $406,193(-6.9)$ & $47,467(3.5)$ & 11.7 & 89,233 & $\triangle 23,112$ \\
\hline 2017 & $573,717(15.8)$ & $26,828(10.2)$ & 4.7 & $478,414(17.8)$ & $55,134(16.2)$ & 11.5 & 95,303 & $\triangle 28,306$ \\
\hline
\end{tabular}

* Unit: Million dollars / ( ) is the increase rate (\%)

** Source: MOTIE and KITA (2015-2017)

In 2017, the amount of Japanese investments in South Korea was U\$1.84 billion (based on reports), an increase of $47.9 \%$ compared to the previous year, and its ratio $(8.0 \%)$ to total investments increased compared to the previous year (5.9\%). According to JETRO Statistics, Japanese companies' investments in South Korea decreased by $29.1 \%$ in 2016 compared to the previous year, and continued to decline later. For Japan, South Korea is the third-largest export destination country and the fourth-largest country of origin of imported goods and has been strengthening its position as a trading partner country for a long time while contributing greatly to the development of both South Korea and Japan. As of 2017, Japan ranked fifth among South Korea's export destination countries and second among countries of origin of imported goods, and was the third-largest trading partner country next to China and the United States. Related investments have also increased rapidly every year, and by 2013, the cumulative investments amounted to $\mathrm{U} \$ 44.5$ billion, so that Japan became the second-largest investment target country of South Korea. Based on cumulative investments, a total of 48,526 investments were made, and the ratio to the total number of investments became $37.9 \%$, which was more than two times higher than that of the United States $(17.8 \%)$ so that Japan ranked 
first.

[Table 2] Trends of investments between South Korea and Japan

\begin{tabular}{|c|c|c|c|c|c|c|c|}
\hline & 2012 & 2013 & 2014 & 2015 & 2016 & 2017 & $1965-2017$ \\
\hline $\begin{array}{c}\text { Japan's investments } \\
\text { in South Korea }\end{array}$ & $45.4(564)$ & $26.9(447)$ & $24.9(352)$ & $16.7(314)$ & $12.5(299)$ & $18.4(328)$ & $427.4(14,030)$ \\
\hline $\begin{array}{c}\text { South Korea's } \\
\text { investments } \\
\text { in Japan }\end{array}$ & $7.4(586)$ & $9.5(645)$ & $5.9(646)$ & $18.6(672)$ & $6.3(635)$ & $6.1(638)$ & $105.6(9,002)$ \\
\hline
\end{tabular}

* Unit: Billion dollars / ( ) is the increase rate (\%)

** Source: MOTIE and Korea Exim Bank (1968-2017)

However, as Japanese society has undergone rapid aging and the direction of "Abenomics" policy has been predominant since the global economic crisis, a new framework for economic cooperation between South Korea and Japan should be explored. In this regard, an argument has been raised that a Korea-Japan FTA can be a successful starting point for new economic cooperation through trade. Therefore, it can be said that the two countries, South Korea and Japan, are at a point in time where they should make an effort to find a prudent and correct method of concluding a Korea-Japan FTA in terms of exchanges in the areas of economy and trade.

For South Korea, which has a high degree of dependence on trade with Japan and high risks of trade conflicts, forming an economic alliance with Japan through an FTA can bring about the effects of resolving trade conflicts with each other and deterring unilateral trade protection actions. An FTA between South Korea and Japan can not only expand the volume of trade with the removal of trade barriers, but also improve real GDP and welfare levels with the dynamic effects of productivity improvement. In particular, as the conclusion of an FTA will improve the environment for investments in South Korea in the regional market and guarantee the transparency of the system, it is expected to be capable of inducing foreign direct investment (FDI) for the purpose of securing a production base in the region to advance into the expanded market. Therefore, in order to understand the current situation and characteristics of trade between South Korea and Japan, and to find a direction for the development of trade between them hereafter, the correlations among the determinants that affect the volume of trade (the GDPs, amounts of direct investments, degrees of dependence on foreign trade, and degrees of economic freedom of the two countries) will be investigated through empirical analyses in this paper[3][4]. As for the composition of this paper, Chapter 1 includes the introduction and background, purpose, and method of the study, and in Chapter 
Empirical Analysis on the Current Status and the Development of Bilateral Trade according to the Promotion of Korea-Japan FTA

2, the present situation of trade between South Korea and Japan, product composition, and the present situations of trade by field are described. In Chapter 3, domestic and foreign studies related to the determinants affecting the volume of trade between South Korea and Japan are reviewed. In Chapter 4, results are derived using data and the implications are summarized. In Chapter 5, the conclusions of this paper are described.

\section{Present Situation of Trade Between South Korea and Japan}

\subsection{History of Development of Trade between South Korea and Japan}

Although Japan accounted for $7.75 \%$ of world trade at the beginning of the 1990s, the ratio gradually decreased to become lower than $0.8 \%$ recently. In addition, Japan was the leading power in Northeast Asia, but its position in world trade has gradually weakened in recent years due to the quantum leap of China, led by its domestic market, the results of the South Korea-China FTA, etc[5]. Therefore, whereas the ratios of manufacturing and service industries were high in Japan and Korea in the past, the two countries should shift direction toward revitalizing their economies through investment diversification hereafter. Data from the Korea Foreign Trade Association indicate that in addition to strong traditional fields such as chemical engineering, electricity, electronics, and metals that have technologies and marketing capabilities, accelerating digital economy-related investments such as investments in content (games), information technology (IT), and platforms (IoT, software) are good for the long-term future and can be the basis for the foregoing.

In addition, it is expected that relieving the problem of market barriers with the conclusion of the Korea-Japan FTA can further activate private trade transactions, leading to dramatic increases in mutual direct investments compared to other regions. As the third period of Abenomics should be greeted now, the relationship between the two countries for practical economic and trade cooperation is thought to be capable of advancing to a stage where it is closer.

Among the top 10 export destination countries of Japan, South Korea has become the third-largest trading partner, and Japan became the fourth-largest trading partner of South Korea next to the European Community (now the European Union) after the United States and China.

The Southeast Asian currency crisis, which started with Thailand's abandonment of the fixed exchange rate system in 1997, hit the economies of Northeast Asian countries as well, and 
consequently caused a series of financial crises that caused unrest in the global economy[6]. The devaluation of the currencies of Southeast Asian countries by $30 \%$ to $40 \%$ caused a credit crunch, and this credit instability led to a movement to recover international capital, which made Asian countries have difficulties in extending borrowings in the short-term foreign debt market. As a result, the South Korean economy was also immensely shocked and severely declined. As the bankruptcies of manufacturers in South Korea increased and the operations of local factories in China were stopped, imports from China decreased dramatically, which greatly affected the economy of Northeast Asia[7].

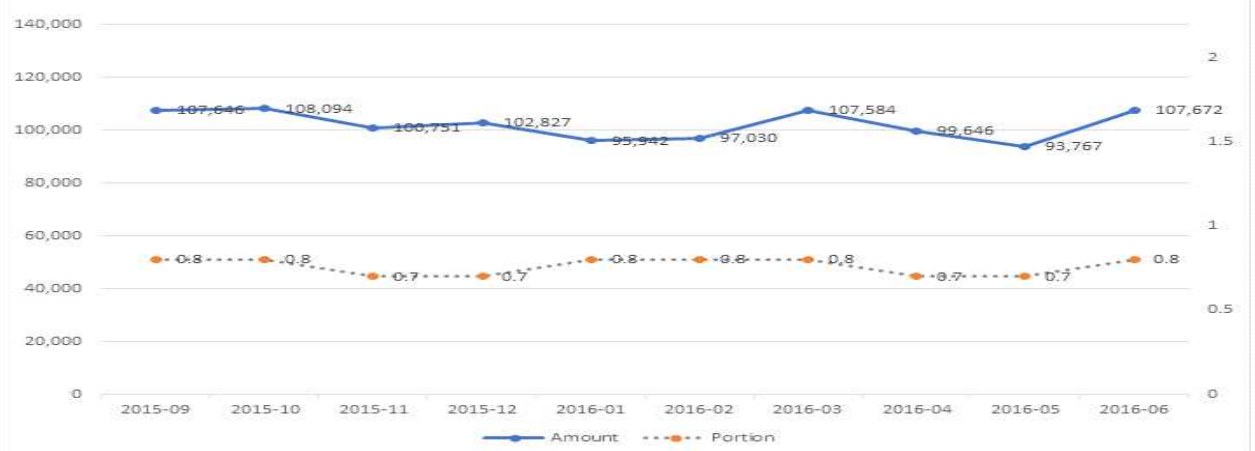

[Fig. 1] Amount and Portion of Japan in World Trade

* Unit: Amount - Million dollars / Portion - \%

** Source: Using statistics from KITA "IMF"

[Fig. 2] Japan's Top 10 Exporting Countries

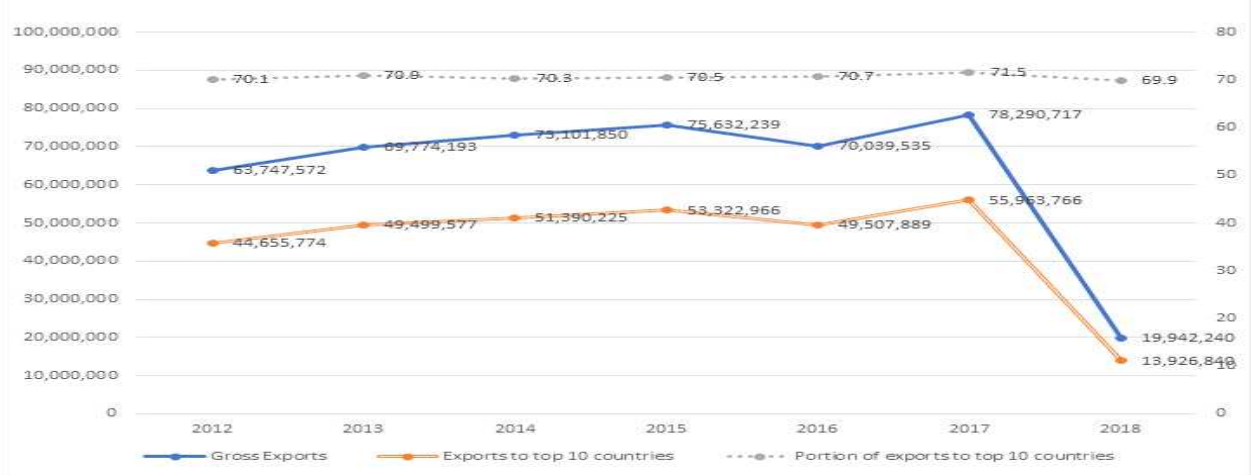

[Fig. 2] Japan's Top 10 Exporting Countries

* Unit: Gross Exports, Exports to top 10 countries - Million dollars /

Portion of exports to top 10 countries - \%

** Source: Using statistics from KITA "Japan Tariff Association" 
Empirical Analysis on the Current Status and the Development of Bilateral Trade according to the Promotion of Korea-Japan FTA

\subsection{Present Status and Trend of Investments in South Korea}

[Table 3] Quarterly trends of Japanese investments in South Korea

\begin{tabular}{|c|c|c|c|c|c|c|c|c|c|c|}
\hline & \multicolumn{2}{|c|}{ First quarter } & \multicolumn{2}{c|}{ Second quarter } & \multicolumn{2}{c|}{ Third quarter } & \multicolumn{2}{|c|}{ Fourth quarter } & \multicolumn{2}{|c|}{ Yearly } \\
\cline { 2 - 11 } & $\begin{array}{c}\text { Amo } \\
\text { unt }\end{array}$ & $\begin{array}{c}\text { Increase } \\
\text { decrease } \\
\text { rate }\end{array}$ & $\begin{array}{c}\text { Amo } \\
\text { unt }\end{array}$ & $\begin{array}{c}\text { Increase } \\
/ \\
\text { decrease } \\
\text { rate }\end{array}$ & $\begin{array}{c}\text { Amo } \\
\text { unt }\end{array}$ & $\begin{array}{c}\text { Increase } \\
/ \\
\text { decreas } \\
\text { e rate }\end{array}$ & Amount & $\begin{array}{c}\text { Increase } \\
/ \\
\text { decrease } \\
\text { rate }\end{array}$ & $\begin{array}{c}\text { Amou } \\
\text { nt }\end{array}$ & $\begin{array}{c}\text { Increas } \\
\text { e/decr } \\
\text { ease } \\
\text { rate }\end{array}$ \\
\hline 2016 & 1.6 & $\triangle 44.3$ & 5.3 & $\triangle 22.3$ & 1.9 & $\triangle 12.6$ & 3.6 & $\triangle 23.5$ & 12.5 & $\triangle 25.2$ \\
\hline 2017 & 4.1 & +153 & 4.1 & $\triangle 22.5$ & 8.7 & +347 & 1.6 & $\triangle 56.5$ & 18.4 & +47.9 \\
\hline
\end{tabular}

* Unit: 100 Million dollars / $\triangle$ is rate (\%)

** Source: KITA "quarterly trends of Japanese investments in South Korea, 2017"

According to the Invest Korea 2017 Annual Report, where the volumes of trade between South Korea and Japan were classified by business type in Japan, the relevant volume of the manufacturing industry increased by $45.7 \%$ compared to the previous year to record U\$970 million, and that of the service industry increased by $58.8 \%$ compared to the previous year to record U\$870 million. In particular, the field of metals in the manufacturing industry showed a volume of U\$320 million, an increase of 7,463\%. The electricity and electronics sector saw an increase of $80.7 \%$, with a volume of U\$240 million, and the field of chemical engineering showed an increase rate of $3.1 \%$ with a volume of U\$260 million. The field of machinery and equipment, however, showed a decrease of $62.1 \%$ with a volume of U\$30 million[8]. The foregoing can be seen as indicating that emerging markets must be discovered and investments in them should be made.

Among other types of service industries, Japanese investments in South Korea's real estate sector recorded U\$300 million, an increase of $619.3 \%$, and the field of business services showed the relevant amount at U\$180 million, an increase of $83.0 \%$. The wholesale and retail sectors showed the relevant amount at U\$160 million, a decrease of 30.7\%. The foregoing can be summarized into the following major features. The fact that Japanese investments in South Korea had been showing downtrends recently that then changed into upward trends in four years to show a full-scale uptrend is encouraging. On reviewing the recent yearly progress of the reported amounts of Japanese FDI in South Korea, it can be seen that it changed from a growing trend to a downward trend and then back to an upward trend as follows: U\$2.69 billion in $2013 \rightarrow$ U\$2.49 billion in $2014 \rightarrow$ U\$1.66 billion in $2015 \rightarrow$ U\$1.25 billion in $2016 \rightarrow$ U\$1.8.4 billion in 2017. As for the reasons for the increase, the robust economic growth rates and expanding trend of mergers and acquisitions (M\&A) of Japan are analyzed to have 
increased Japanese FDI in the world, and affected the increase in investments in South Korea. According to an announcement by the Ministry of Finance of Japan, the amount of Japanese overseas foreign direct investments (OFDI) from January to September was 14,433.8 billion yen, an increase of $7.1 \%[9]$. In line with the market changes, it is expected that an era of accelerated investment diversification from strong traditional fields such as the chemical industry, electricity/electronics, and metals to digital economy-related areas such as contents (games), information technology (IT), and platforms (IoT, software) is occurring and should be greeted and preoccupation of the relevant markets is thought to be helpful for increases in the volume of trade between South Korea and Japan. As a major example of FDI from Japan, it is said that K Co., a Japanese steel company, recently acquired a stake in a steel material company in South Korea, established a new joint venture, and is making investments for the production of high-strength aluminum. In addition, it is said that D Co., which produces secondary battery separators and materials for secondary batteries, is actively investing to proactively respond to the rapidly increasing global demand for secondary batteries by establishing a value chain with a South Korean finished product manufacturing company. It is expected that various exchanges intended to increase the volume of trade for the development of South Korea and Japan will be actively carried out.

[Table 4] Status of Human Exchanges between South Korea and Japan

\begin{tabular}{|c|c|c|c|c|c|c|c|}
\hline Division & 2011 & 2012 & 2013 & 2014 & 2015 & 2016 & 2017 \\
\hline $\begin{array}{c}\text { No. of entrants into South } \\
\text { Korea }\end{array}$ & 979.4 & $1,114.0$ & $1,217.6$ & $1,420.2$ & $1,323.2$ & $1,724.2$ & $1,333.6$ \\
\hline $\begin{array}{c}\text { Japanese visitors to South } \\
\text { Korea }\end{array}$ & $\begin{array}{c}328.9 \\
(8.8)\end{array}$ & $\begin{array}{c}351.9 \\
(7.0)\end{array}$ & $\begin{array}{c}274.8 \\
(\triangle 21.9)\end{array}$ & $\begin{array}{c}228.0 \\
(\triangle 17.0)\end{array}$ & $\begin{array}{c}183.8 \\
(\triangle 19.4)\end{array}$ & $\begin{array}{c}229.8 \\
(25.0)\end{array}$ & $\begin{array}{c}231.1 \\
(0.6)\end{array}$ \\
\hline Ratio of Japanese & 33.6 & 31.6 & 22.6 & 16.1 & 13.9 & 13.3 & 17.3 \\
\hline No. of entrants into Japan & 621.9 & 835.8 & $1,036.4$ & $1,341.3$ & $1,973.7$ & $2,404.0$ & $2,869.0$ \\
\hline $\begin{array}{c}\text { South Korean visitors to } \\
\text { Japan }\end{array}$ & 165.8 & 204.4 & 245.6 & 275.5 & 400.2 & 509.0 & 714.0 \\
$(\triangle 32.0)$ & $(23.3)$ & $(20.2)$ & $(12.2)$ & $(45.3)$ & $(27.2)$ & $(40.3)$ \\
\hline Ratio of South Koreans & 26.7 & 24.4 & 23.7 & 20.5 & 20.3 & 21.2 & 24.9 \\
\hline Total & 494.7 & 556.2 & 520.4 & 503.5 & 584.0 & 738.8 & 945.1 \\
\hline
\end{tabular}

* Unit:10,000 / ( ) is rate (\%)

** Source: Korea Tourism Organization

As of 2017, the ratio of Japanese entrants to total foreign entrants into South Korea was $17.3 \%$, which was second highest next to that of Chinese entrants. This indicates that human exchanges are also actively being made, centering on Northeast Asia. In addition, if the 
Empirical Analysis on the Current Status and the Development of Bilateral Trade according to the Promotion of Korea-Japan FTA

Korea-Japan FTA is concluded, human exchanges are seen to increase further as the diversity of other commodity markets and service markets will be increased.

\section{Review of Previous Studies}

Since the rationale was proved by many scholars, empirical analysis using the gravity model has been more actively conducted. In foreign countries, the relevant studies were conducted by Frankel (1997), Garman (1999), Wall (1999), Tamirisa (1999), and Evenett and Keller (2002), and in South Korea as well, the gravity model has been diversely applied to analyze international trade phenomena. Kim (2009) analyzed the trade patterns between South Korea and major countries, and found that economic scales and per capita incomes were factors that have important effects, and distance variables were factors that had negative effects on trade volumes. Among economic integration variables, ASEAN had positive $(+)$ effects, while the EU had no significant effect. Using panel data from 1992 to 2009 from 76 countries, Jang (2010) reached the conclusion that the oil product trade pattern of South Korea was consistent with the general gravity model and additionally analyzed the effects of regional economic cooperation bodies. Kwon (2015) analyzed the trade patterns between South Korea and major trading partners using the gravity model, and additionally analyzed ASEAN and FTAs to confirm that economic integration factors affect trade[10]. Shin and Kwon (2015) used the gravity model to estimate the effect of the AEO MRA to increase trade and derived a result consistent with the general assumption of the model.

[Table 5] Summary of Research

\begin{tabular}{|c|c|c|}
\hline Researcher & Research Content & Results \\
\hline $\begin{array}{c}\text { Hyo-Jeong Kim, } \\
(2009)\end{array}$ & $\begin{array}{c}\text { Determinants of } \\
\text { intra-industry trade among } \\
\text { OECD member countries }\end{array}$ & $\begin{array}{c}\text { Economic scales and per capita income have }(+) \\
\text { effect, distance has (-) effect }\end{array}$ \\
\hline $\begin{array}{c}\text { Cheol-Ho Jang, } \\
(2010)\end{array}$ & $\begin{array}{c}\text { Petroleum Product Trade } \\
\text { Patterns }\end{array}$ & $\begin{array}{c}\text { Consistent with the general gravity model. } \\
\text { A increase in the economic scale of the two } \\
\text { countries increases trade by 0.36\%, and a 1\% } \\
\text { increase in distance between the two countries } \\
\text { decreases trade by 2.64\%. }\end{array}$ \\
\hline $\begin{array}{c}\text { Yoon-Jeong Kwon, } \\
(2015)\end{array}$ & $\begin{array}{c}\text { Trade patterns between } \\
\text { South Korea and major } \\
\text { countries }\end{array}$ & $\begin{array}{c}\text { Transformed and applied the gravity model into } \\
\text { diverse forms and conducted analysis to find out } \\
\text { that the economy integration factor has effects on } \\
\text { trade. }\end{array}$ \\
\hline Dae-Cheol Shin, & Analysis of the trade & Proved the effectiveness of AEO MRA as a trade \\
\hline
\end{tabular}



Yeong-Min Kwon,
(2015) facilitation effect of the AEO

Mutual Recognition Agreement policy tool through the gravity model

\section{Empirical Analysis}

\subsection{Research model}

Simple regression analysis is the simplest form of regression analysis, and is conducted in cases where there is only one independent variable. However, in regression analyses related to the actual economy, multiple independent variables exist in most cases. Therefore, multiple regression analysis is required to analyze most economic models[11].

In this paper, the relationships among the volume of trade between South Korea and Japan, their GDPs[12], the amounts of direct investments[13], and the degrees of external openness of the two countries[14] were explained using the multiple regression analysis method.

(1) Multiple Regression Analysis

$$
\ln T_{\mathrm{kc}}=\beta_{0}+\beta_{1} \ln G D P_{k}+\beta_{2} \ln G D P_{c}+\beta_{3} \ln I_{k}+\beta_{4} \ln I_{c}+\beta_{5} \ln T D_{k}+\beta_{6} \ln T D C+\epsilon
$$

where, $T_{\mathrm{kc}}$ is the volume of trade between South Korea and Japan

$\mathrm{GDP}_{\mathrm{k}}$ is the GDP of South Korea

$\mathrm{GDP}_{\mathrm{c}}$ is the GDP

$I_{\mathrm{k}}$ is the amount of direct investments by South Korea in Japan

$I_{\mathrm{c}}$ is the amount of direct investments by Japan in South Korea

$T D_{k}$ is the degree of external openness of South Korea

$T \mathrm{D}_{\mathrm{c}}$ is the degree of external openness of Japan

$\epsilon$ is the error term

\subsection{Data Collection and Study Hypothesis}

The empirical analysis in this study was carried out with yearly data from 1991 to 2017 collected for this paper. Statistics from the Korea Foreign Trade Association were adopted for the volumes of trade between South Korea and Japan, statistics from the World Bank were used for the GDPs of the two countries, and statistics from the Export-Import Bank of Korea were used for South Korean direct investments in Japan. The data published by JETRO 
Empirical Analysis on the Current Status and the Development of Bilateral Trade according to the Promotion of Korea-Japan FTA

Statistics of Japan were used for Japanese direct investments in South Korea, and the conclusion of the FTA between South Korea and Japan was set as a qualitative variable to see if the free trade agreement affects the volume of trade. The degree of external openness to trade is total foreign trade capacity/GDP, and the total foreign trade capacity of the two countries is based on statistics from the Korea Foreign Trade Association. The degree of external openness of trade is the total volume of external trade/GDP and the total volumes of external trade of the two countries were determined using statistics from the Korea Foreign Trade Association.

[Table 6] Hypotheses Regarding the Determinants of Trade

\begin{tabular}{|c|c|c|}
\hline No. & Major contents of hypothesis & Expected value \\
\hline $1-1$ & $\begin{array}{c}\text { The higher the GDPs of South Korea and Japan, the more positively the } \\
\text { volume of trade between South Korea and Japan will be affected. }\end{array}$ & + \\
\hline $2-1$ & $\begin{array}{l}\text { The larger the amounts of direct investments between South Korea and Japan, } \\
\text { the more positively the volume of trade between South Korea and Japan will } \\
\text { be affected. }\end{array}$ & + \\
\hline $3-1$ & $\begin{array}{c}\text { The degrees of external openness of trade of South Korea and Japan will } \\
\text { have positive effects on the volume of trade between South Korea and Japan. }\end{array}$ & + \\
\hline $4-1$ & $\begin{array}{c}\text { The conclusion of the FTA between South Korea and Japan will have positive } \\
\text { effects on the volume of trade between South Korea and Japan. }\end{array}$ & + \\
\hline
\end{tabular}

\subsection{Results of Empirical Analysis}

This paper tested the hypotheses presented in [Table 6] by analyzing statistical data using the analysis tools of EXCEL. Using an empirical analysis method in which yearly data for 27 years from 1991 to 2017 were collected and simple regression analyses were conducted, the following results were obtained. [Table 7] shows correlations between dependent variables and independent variables.

[Table 7] Analysis Correlations between Dependent Variables and Independent Variables

\begin{tabular}{|c|c|c|c|c|c|c|}
\hline Model & $\begin{array}{c}\text { Total trade } \\
\text { volume between } \\
\text { South Korea and } \\
\text { Japan y }\end{array}$ & $\begin{array}{c}\text { GDP of } \\
\text { South } \\
\text { Korea }\end{array}$ & $\begin{array}{c}\text { GDP of } \\
\text { Japan }\end{array}$ & $\begin{array}{c}\text { Amount of } \\
\text { South Korean } \\
\text { investments in } \\
\text { Japan }\end{array}$ & $\begin{array}{c}\text { Amount of } \\
\text { overseas exports } \\
\text { of Japan }\end{array}$ & $\begin{array}{c}\text { Amount of } \\
\text { Japanese } \\
\text { investments in } \\
\text { South Korea }\end{array}$ \\
\hline $\begin{array}{c}\text { Total trade } \\
\text { volume between } \\
\text { South Korea and }\end{array}$ & 1 & & & & & \\
\hline
\end{tabular}




\begin{tabular}{|c|c|c|c|c|c|c|}
\hline Japan & & & & & & \\
\hline $\begin{array}{c}\text { GDP of South } \\
\text { Korea }\end{array}$ & 0.879 & 1 & & & & \\
\hline GDP of Japan & 0.669 & 0.455 & 1 & & & \\
\hline $\begin{array}{l}\text { Amount of South } \\
\text { Korean } \\
\text { investments in } \\
\text { Japan }\end{array}$ & 0.768 & 0.864 & 0.339 & 1 & & \\
\hline $\begin{array}{c}\text { Amount of } \\
\text { overseas exports } \\
\text { of Japan }\end{array}$ & 0.516 & 0.396 & 0.497 & 0.455 & 1 & \\
\hline $\begin{array}{l}\text { Amount of } \\
\text { Japanese } \\
\text { investments in } \\
\text { South Korea }\end{array}$ & 0.874 & 0.809 & 0.597 & 0.742 & 0.588 & 1 \\
\hline
\end{tabular}

[Table 8] to [Table 11] show the results of estimation by the simple regression method, which are further discussed in the following sub-sections 4.3.1 to 4.3.3.

[Table 8] Results of Estimation by Simple Regression - 1

\begin{tabular}{|c|c|c|c|c|}
\hline Model & $\mathrm{B}$ & Standard error & $\mathrm{t}$ & Significance probability \\
\hline Constant & $-2.017^{* *}$ & 1.113 & $-1,811$ & .077 \\
\hline GDP of Japan & $.657^{*}$ & .082 & 8.057 & .000 \\
\hline GDP of South Korea & $.330^{*}$ & .146 & 2.255 & .029 \\
\hline $\begin{array}{c}\text { Amount of Japanese direct } \\
\text { investments in South Korea }\end{array}$ & $-.015^{* *}$ & .008 & -1.847 & .071 \\
\hline $\begin{array}{c}\text { Amount of South Korean direct } \\
\text { investments in Japan }\end{array}$ & $.072^{*}$ & .003 & 2.416 & .020 \\
\hline $\begin{array}{c}\text { Degree of external openness of } \\
\text { Japan }\end{array}$ & $.014^{*}$ & .002 & 6.307 & .000 \\
\hline $\begin{array}{c}\text { Degree of external openness of } \\
\text { South Korea }\end{array}$ & $.006^{*}$ & .002 & 3.209 & .002 \\
\hline
\end{tabular}

${ }^{* * *} p<0.01,{ }^{* *} p<0.05,{ }^{*} p<0.1$

[Table 9] Results of Estimation by Simple Regression - 2

\begin{tabular}{|c|c|c|}
\hline $\mathrm{R}^{2}$ & Sig. F Change & Durbin-Watson \\
\hline .890 & .000 & 1.279 \\
\hline
\end{tabular}

[Table 10] Results of Estimation by Simple Regression - 3

\begin{tabular}{|c|c|c|c|c|}
\hline Variable & Coefficients & Standard error & $\mathrm{t}$ statistics & P-value \\
\hline Y Intercept & -20883.24 & 17141.943 & -1.218 & 0.237 \\
\hline GDP of South Korea & 0.0316 & 0.011 & 2.764 & 0.011 \\
\hline
\end{tabular}


Empirical Analysis on the Current Status and the Development of Bilateral Trade according to the Promotion of Korea-Japan FTA

\begin{tabular}{|c|c|c|c|c|} 
GDP of Japan & 0.010 & 0.003 & 2.601 & 0.017 \\
\hline $\begin{array}{c}\text { Amount of South Korean } \\
\text { investments in Japan }\end{array}$ & 3.275 & 14.614 & 0.224 & 0.824 \\
\hline $\begin{array}{c}\text { Amount of overseas exports of } \\
\text { Japan }\end{array}$ & 0.001 & 0.019 & 0.051 & 0.959 \\
\hline $\begin{array}{c}\text { Amount of Japanese investments in } \\
\text { South Korea }\end{array}$ & 6.598 & 3.427 & 1.924 & 0.068 \\
\hline Korea-Japan Free Trade Agreement & 0 & 0 & 0 & 0 \\
\hline
\end{tabular}

[Table 11] Analysis of Variance

\begin{tabular}{|c|c|c|c|c|c|c|}
\hline \multicolumn{2}{|c|}{ Model } & Sum of squares & Degrees of freedom & Mean square & F & Significance probability \\
\hline \multirow{4}{*}{1} & Regression model & 5.027 & 6 & 8.378 & 2.14 & .000 \\
\cline { 2 - 7 } & Residual & 1.421 & 182 & & & \\
\cline { 2 - 7 } & Total & 5.169 & 188 & & & \\
\hline
\end{tabular}

On reviewing the "results of estimation by simple regression" shown in the tables above, it can be seen that the determinants that affect the volume of trade between South Korea and Japan trade are as follows.

\subsubsection{Effects of GDP}

In the present study model, it was verified that when the GDP of Japan increased by $1 \%$, the trade volume between South Korea and Japan increased by $0.657 \%$. In the case of South Korea, when the GDP increased by $1 \%$, the trade volume between South Korea and Japan also increased by $0.330 \%$. Between the effects on the volume of trade between South Korea and Japan, the effect of the GDP of Japan can be regarded to be larger than twice that of South Korea. As derived in general previous studies, the results of this study indicated that the higher the GDPs of the two countries, the larger the positive effects on the volume of trade between them, and the results identical to the contents assumed above were derived.

\subsubsection{Effects of Direct Investment}

It was assumed that South Korean direct investment in Japan had positive $(+)$ effects on the trade volume between South Korea and Japan, and the result was found to be consistent with the expected value. When South Korean investments in Japan increased by $1 \%$, the trade volume between South Korea and Japan increased by $0.072 \%$. However, in the case of Japan, interesting results appeared. When Japanese investments in South Korea increased by $1 \%$, the trade volume between South Korea and Japan decreased by $-0.015 \%$. In addition, it can be 
seen that the effect of Japanese direct investments in South Korea on the volume of trade between South Korea and Japan is not very significant. On reviewing the results of this analysis, it can be seen that Japanese direct investments in South Korea have shown an increasing trend in recent years, but investments related to the digital economy are regarded to be more intensively made in earnest in addition to the traditional manufacturing industry sector that can induce increases in the volume of trade between the two countries.

\subsubsection{Effect of the Degree of External Openness}

The degree of external openness is a good indicator that enables the estimation of the volume of trade for a country. In general, a high degree of external openness means that the country's economy is closely related to the economies of other countries. In this study, when the degree of external openness of trade of Japan increased by $1 \%$, the volume of trade between South Korea and Japan increased by $0.014 \%$. It was verified that when the degree of external openness of trade of South Korea increased by $1 \%$, the volume of trade between South Korea and Japan increased by $0.006 \%$.

\subsection{Implications}

The volume of trade between South Korea and Japan has continuously increased since the establishment of diplomatic relations. Further, it showed a decreasing trend due to the rapid development of China and the global economic recession thereafter, and has been recently developing to show an increasing trend. Trade relations between South Korea and Japan have been good, and the two countries have become important trade partners. Given the aforementioned results of analysis, the following implications were derived.

First, it can be seen that among the effects on the volume of trade between South Korea and Japan, the effect of the GDP of Japan is more than twice that of the GDP of South Korea. Therefore, it can be predicted that if Abenomics is maintained, the GDP of Japan will continue to increase hereafter, and if this trend continues, the trade volume between South Korea and Japan will increase further.

Second, with regard to future Japanese investments in South Korea, portfolio investments and foreigners' investments in real estate should be suppressed, and instead, Japanese investments should be guided to industries that can lead to job creation and increases in production and trade and green fields. In addition, efforts should be made for rational labor movement and the supply of necessary manpower, and improvements are needed, such as the reduction of corporate taxes, abolition of tariffs, and reduction of rents of industrial complexes. 
Empirical Analysis on the Current Status and the Development of Bilateral Trade according to the Promotion of Korea-Japan FTA

Third, since the current scale of economic exchanges between South Korea and Japan is large and the two countries' economic forms include mutually complementary industrial structures, the conclusion of the Korea-Japan FTA is expected to be capable of expanding the trade and investments between South Korea and Japan further. Therefore, it can be said that early conclusion of the FTA should be promoted[15].

In addition, in order for the Korea-Japan FTA to become a basis for economic integration in East Asia in the future, the FTA should be promoted to encompasses not only the liberalization of the product sector, but also the elimination of non-tariff barriers[16], liberalization of the service and investment sectors, protection of investors, and other trade norms and cooperation.

\section{Conclusion}

This study aimed to explore the direction of development of trade between South Korea and Japan prior to the conclusion of the Korea-Japan FTA. To this end, the authors examined the volume of trade between the countries and related characteristics, and derived empirical results using yearly data for 27 years from 1991 to 2017. In that regard, factors affecting the volume of trade between South Korea and Japan were empirically analyzed in this paper. The volume of trade was set as a dependent variable for the empirical analysis, and the GDPs of South Korea and Japan, the amounts of direct investments of South Korea and Japan in other countries, the degrees of external openness of trade of both countries which are a policy variable, were set as independent variables.

The results of analysis indicated that the higher the GDPs of South Korea and Japan, the more significant the positive $(+)$ effects of the GDPs on the volume of trade between them. Whereas South Korean direct investments in Japan were shown to have positive (+) effects on the volume of trade between South Korea and Japan, Japanese direct investments in South Korea were shown to have negative (-) effects on the volume of trade. It was shown that the higher the degree of external openness of trade of South Korea and Japan, the more significant the effects on the volume of trade between the countries. Therefore, in order to continue the expansion of trade between South Korea and Japan, not only should the economies of the two countries grow more, but also the amounts of direct investments should be increased. In particular, Japanese direct investments in industries in South Korea should be further activated. In addition, the trade barriers that may bring about the effect to reduce the volume of trade should be removed, and trade custom clearances should be smoothened and accelerated[17]. 
In addition, the best way to realize additional development of trade between South Korea and Japan should be the conclusion of an FTA. With an FTA, the trade cooperation system between the two countries will be further simplified. Therefore, in order to go toward a path for mutual win-win that can bring about economic benefits and positive political effects for the two countries, efforts should be made to finally conclude an FTA between them.

Meanwhile, this paper has limitations for it did not consider the degree of economic freedom, market interest rates and unit labor costs as determinants, which are additional factors that can affect the trade volume between South Korea and Japan. Therefore, a future task is needed to conduct a more in-depth study using other additional factors as determinants of trade volumes between the countries.

\section{References}

[1] Nam-Gon Kim, Knowledge Information Firm's Corporate Divestitures, Asia Pacific Fusion Research Interchange Paper, (2018), Vol.4, No.1, pp.63-70.

[2] Da-Mi Baek, Comparison of Exports to Korea and Japan according to the yen low, Korea: Hyundai Research Institute, (2015)

[3] Li Jian, A Study on the Development Plan of the International Trade between Korea and China, WooSuk University, Master's Thesis,,(2010)

[4] Su-Hee Hong, Hyun-Wook Ryu, Environmental Violations and Financial Performance of Firms in Korea: Empirical Evidence, Asia Pacific Fusion Research Interchange Paper, (2019), Vol.5, No.4, pp.75-82.

[5] Chung-Bae Lee, Jin-Ho Nho, Yun-Hee Seo, A Study on the Effects of a Korea-China FTA and the Comparison of their Strategies for the FTA, Korea Research Society For Customs, (2011), Vol.12, No.4, pp.211-235.

[6] Economic Team, 20 Years After the Asian Financial Crisis, Korea: The Bank of Korea, (2017)

[7] Meng Xia, (An) Analysis of Korea-China Trade Structure Features and Competitiveness by Item, BuSan University, Master's Thesis,, (2013)

[8] Invest Korea, 2017 Annual Report, Korea: Kotra, (2018)

[9] Investment attraction department, 2018 Annual Report, Korea: MOTIE, (2019)

[10] Sang-Ok Lee, A Study on analysis of trade pattern of Korea by Gravity Model, Journal of Korea Research Society For Customs, Korea Research Society for Customs, (2011), Vol.12, No.4, pp.417-432.

[11] Beom-Jo Park, Applied econometrics using R statistical software, Korea: Sigma Press Co., Ltd., (2013)

[12] Sang-Wook Nam, A Study on the Trade Patterns and Trade Risk of China Using the Gravity Models, 
Empirical Analysis on the Current Status and the Development of Bilateral Trade according to the Promotion of Korea-Japan FTA

Journal of Risk Managerment, (2016), Vol.27, No.2, pp.1-27.

[13] Hyuk-Hwang Kim, Hea-Jung Hyun, The Impacts of Outward FDI on Export and Import in Korea, Journal of International Trade Industry Studies, (2011), Vol.16, No.3, pp.1-28.

[14] Seo-In Back, Hyun-Suk Song, A Study on the Influence of Foreign Trade External openness on Korea's Economic and Industrial Growth, Korea: KOSTAT, (2012), No.25, pp.1-32.

[15] Li Ai Ping, (A) Study on the Possibility and Necessity of Conclusion for FTA between Korea and China, DanKook University, Master's Thesis, (2012)

[16] Sang-Hoon Lee, Bu-Yong Kim, Jin-Hee Park, Ji-Na Yeo, China's Non-Tariff Barriers and Implications for Korea-China FTA, Korea: Korea Institute for International Economic Policy, (2012)

[17] Peng Qi, The Determinants of Inflow FDI and Trade between OECD and China, DaeGu University, Master's Thesis, (2013) 